\title{
Evaluation of Different Pre-sowing Seed Treatment for Improving Growth, Yield and Yield Attributes of Finger Millet (Eleusine coracana (L.) Gaertn)
}

\author{
Nuthalapati Karthik*, Arun Kumar Chaurasia, \\ Rajaka Karthik Kumar and Karunakar Reddy Guduri
}

Department of Genetics and Plant Breeding, Naini Agricultural Institute, Sam Higginbottom University of Agriculture, Technology and Sciences, Prayagraj, Uttar Pradesh, India

*Corresponding author

\section{A B S T R A C T}

Ke ywords

Finger millet, Mannitol, $\mathrm{KCl}$, $\mathrm{KNO}_{3}, \mathrm{CaCl}_{2}$, Botanicals, Growth and yield attributes, Parthenium leaf extract, Neem leaf extract, Tulasi leaf extract, Priming, Pre-sowing, Seed Treatment

Article Info

Accepted:

12 January 2021

Available Online:

10 February 2021
The experiment was conducted in experimental field, Department of Genetics and Plant Breeding, Sam Higginbottom University of Agriculture, Technology and Sciences, Prayagraj (U.P.) during Kharif season 2019, in order to standardize the suitable pre-sowing seed treatment of Finger millet. Differentpre-sowing seed treatments including control were evaluated by screening 12 hour viz., $\mathrm{T}_{0}-$ Control, $\mathrm{T}_{1}-\mathrm{DH}_{2} \mathrm{O}, \mathrm{T}_{2}-$ Manitol @ 2\%, $\mathrm{T}_{3}-$ Manitol@4\%, $\mathrm{T}_{4}-\mathrm{KCl} @ 2 \%, \mathrm{~T}_{5}-\mathrm{KCl} @ 4 \%, \mathrm{~T}_{6}-\mathrm{KNO}_{3} @ 2 \%, \mathrm{~T}_{7}-$ $\mathrm{KNO}_{3} @ 4 \%, \mathrm{~T}_{8}-\mathrm{CaCl}_{2} @ 2 \%, \mathrm{~T}_{9}-\mathrm{CaCl}_{2} @ 4 \%, \mathrm{~T}_{10}-$ Parthenium leaf extract@5\%, $\mathrm{T}_{11}$ - Neem leaf extract @ 5\%, $\mathrm{T}_{12}$ - Tulasi leaf extract @ 5\%. It was found that all the pre-sowing seed treatments including with control shows significant difference and lowest taken days to $50 \%$ flowering by $\mathrm{T}_{7}-$ $\mathrm{KNO}_{3} @ 4 \%$ and number of fingers per panicle, biological yield, harvest index were observed high in $\mathrm{T}_{5^{-}} \mathrm{KCl} @ 4 \%$ in field experiment. These study helps to improve the growth, yield and yield attributes by the help of Pre-sowing seed treatment which is simple method, economic and no requirement for expensive equipment, non-toxic and eco-friendly.

\section{Introduction}

Millets are some of the oldest one cultivated crops and important component in dry land agriculture. Millets refers to a group of annual grasses mainly found in the arid and semi-arid regions of the world. Small millets represent a diverse group of small seeded annual cereal grasses used for food, feed and forage purpose. These crops can face wide range of temperatures, moisture-regimes and input conditions and are capable to supply food and feed to millions of dry-land farmers, particularly in the developing world (Kaur et al., 2012). Finger millet, ranks fourth in importance among millets after sorghum, pearl millet and foxtail millet in the world (Upadhyaya et al., 2007), Finger Millet 
(Eleusine coracana (L.) Gaertn) is an allopolyploid with chromosome number $2 n=$ $4 x=36$ and evolved from a cross between two diploid species. Finger millet, being a hardy crop, is known to be least affected by biotic and abiotic stresses (Dwivedi et al., 2012), it can thrive under a variety of harsh environmental conditions, varieties of factors viz., poor soil fertility, diseases and insectpests attack (Bouis, 2000). It is rich in calcium (0.34\%), Dietary fiber (18\%), Phytates $(0.48 \%)$, protein $(6 \%-13 \%)$ minerals $(2.5 \%-3.5 \%)$, and phenolics $(0.3 \%-3 \%)$. The rapid and uniform field emergences are known to be the two essential pre-requisites to increase yield, quality, and ultimately to gain profit in crop.

Among the seed quality enhancement techniques, Seed priming is a pre-sowing strategy for influencing seedling development by modulating pre germination metabolic activity prior to emergence of the radicle and generally enhances rapid, uniform emergence and plant performance to achieve better growth and yield (McDonald, 2000). Hydro priming is a controlled hydration by soaking seeds in solution of low water potential followed by re-drying that allows per germination metabolic activities to proceed. Osmopriming include alternate wetting and drying, pre germination and controlled hydration by means of an osmoticum such as poly ethylene glycol PEG, Manitol. Halopriming is one of the very important seed treatment technique apply with salt solution like as $\mathrm{KCl}, \mathrm{CaCl}_{2}, \mathrm{NaCl}, \mathrm{CaCl}_{2}$ and $\mathrm{KNO}_{3}$ solution concentration. Organic-primingin which organic plant extract such as Neem leaf extract, Tulasi leaf extract is used. In the view of this, the present investigation was taken up to evaluate pre-sowing seed treatment for improving growth and Yield attributes in Finger millet. The seed bio-priming is an effective seed treatment to increase the rate, rapid emergence, uniformity of emergence and crop establishment in most of the crops (Rawat et al., 2011). It integrates the biological and physiological aspects of enhancing growth, disease control and increase in yield, which involves coating the seed with biological agents and incubating the seed under warm, moist conditions.

\section{Materials and Methods}

The Research work was carried out at experimental field of Seed science and Technology, Department of Genetics and Plant Breeding, Sam Higginbottom Institute of Agriculture, Technology and Science, Naini Agriculture Institute, Prayagraj (U.P), during Kharif season 2019 to evaluate Seeds of finger millet(VR708) were obtained from Directorate of Research, SHUATS, Prayagraj, UP.

The treatments were represented as, $\mathrm{T}_{0}$ Control, $\mathrm{T}_{1}$ - Distilled water, $\mathrm{T}_{2}$ - Mannitol @ 2\%, $\mathrm{T}_{3}$ - Mannitol @ 4\%, $\mathrm{T}_{4}$ - Potassium Chloride@2\%, $\mathrm{T}_{5}$ - Potassium Chloride@ $4 \%, \mathrm{~T}_{6}$ - Potassium nitrate @ 2\%, $\mathrm{T}_{7}$. Potassium nitrate @ 4\%, T - Calcium chloride @ 2\%, $\mathrm{T}_{9}$ - Calcium chloride @4\%, $\mathrm{T}_{10}$ Parthenium leaf extract@5\%, $\mathrm{T}_{11}$ - Neem leaf extract@5\%, T12 - Tulasi leaf extract @ $5 \%$

The Seeds were divide into thirteen subsamples each, one from thirteen were kept as control. Then the seeds are soaked in freshly prepared solutions i.e. Potassium Chloride @ $2 \%$ and $4 \%$, Potassium nitrate @ 2\% and 4\%, Calcium chloride@2\% and 4\%, Mannitol@ 2\% and 4\%,Parthenium leaf extract@5\%, Neem leaf extract@5\%, Tulasi leaf extract @ 5\% and distil water for $12 \mathrm{hrs}$. The Soaked seeds were dried back to orginal moisture content at room temperature $25^{\circ} \mathrm{C}$ for $24 \mathrm{hrs}$.

To carryout the experiment the seeds were sown in thirteen plots each in three 
replications with spacing of $22.5 \times 10 \mathrm{~cm}$ using line sowing methods following Randomize Block Design.

Data collected of field emergence, it was expressed in percentage, Days to $50 \%$ flowering, Plant height of 60 and 90 days, it was expressed in centimeter, number of fingers per panicle, seed yield per plot expressed in grams, seed yield per plant expressed in grams, Biological yield and Harvesting index. The data recorded from field were analysed statistically following the method of analysis of variance (Fisher, 1948).

\section{Prepration of solution}

The solution of KCL (2\%and 4\%) was prepared by dissolving $2 \mathrm{gm}$ and $4 \mathrm{gm}$ of $\mathrm{KCL}$ in $100 \mathrm{ml}$ of distilled water, each in separate beakers. The solution of $\mathrm{KNO}_{3}(2 \%$ and $4 \%$ ) was prepared by dissolving $2 \mathrm{gm}$ and $4 \mathrm{gm}$ of $\mathrm{KNO}_{3}$ in $100 \mathrm{ml}$ of distilled water, each in separate beakers. The solution of $\mathrm{CaCl}_{2}$ ( $2 \%$ and $4 \%$ ) was prepared by dissolving $2 \mathrm{gm}$ and $4 \mathrm{gm}$ of $\mathrm{CaCl}_{2}$ in $100 \mathrm{ml}$ of distilled water, each in separate beakers. The solution of Mannitol (2\%and 4\%) was prepared by dissolving $2 \mathrm{gm}$ and $4 \mathrm{gm}$ of Mannitol in $100 \mathrm{ml}$ of distilled water each in separate beakers. The Neem leaf extract, Parthenium leaf extract, Tulasi leaf extract was prepared by drying of neem leaf and made into fine powder, $5 \mathrm{gm}$ of each powder is dissolved into $100 \mathrm{ml}$ of distilled water to make $5 \%$ solution

\section{Results and Discussion}

A field experiment was conducted to Evaluate different pre-sowing seed treatment for improving growth, yield and yield attributes in Finger millet (Eleusine coracana (L.) Gaertn). Mean performance of growth and yield characters of finger millet shown in Table I
The field emergence percentage ranged from $76.33 \%$ to $87.67 \%$ with mean value of $81.97 \%$. Significantly maximum field emergence percentage (87.67\%) was recorded by $\mathrm{T}_{5}-\mathrm{KCl} @ 4 \%$ and it was followed by $\mathrm{T}_{7}$ - $\mathrm{KNO}_{3} @ 4 \%$ (87.00\%), $\mathrm{T}_{9}-\mathrm{CaCl}_{2} @ 4 \%$ (86.33\%)and $\mathrm{T}_{2}$ - Mannitol @ 2\% (85.00\%). Minimum field emergence percentage was recorded by $\mathrm{T}_{0}-$ Control $(76.33 \%)$. Days to $50 \%$ flowering ranged from 56 to 70 days with mean value of 64. Significantly minimum taken days to $50 \%$ flowering (56) was recorded by $\mathrm{T}_{7}-\mathrm{KNO}_{3} @ 4 \%$ and it was followed by $\mathrm{T}_{5}-\mathrm{KCl} @ 4 \%$ (58.00), $\mathrm{T}_{2}-$ Mannitol@2\% (60.00) and $\mathrm{T}_{4}-\mathrm{KCl} @ 2 \%$ (61.00).Maximum days to $50 \%$ flowering were recorded by $\mathrm{T}_{0}-$ Control (70.00). Plant height at 60 DAS ranged from $41.07 \mathrm{~cm}$ to $52.95 \mathrm{~cm}$ with mean value of $46.18 \mathrm{~cm}$. Significantly maximum plant heightat 60 DAS $(52.95 \mathrm{~cm})$ was recorded by $\mathrm{T}_{2}-$ Mannitol@2\% and it was followed by $\mathrm{T}_{5}-$ $\mathrm{KCl} @ 4 \%(51.93 \mathrm{~cm}), \mathrm{T}_{7}-\mathrm{KNO}_{3} @ 4 \%$ $(49.48 \mathrm{~cm})$ and $\mathrm{T}_{4}-\mathrm{KCl} @ 2 \%(49.03$ $\mathrm{cm})$.Minimum plant height at 60 DAS was recorded by $\mathrm{T}_{0}-$ Control $(41.07 \mathrm{~cm})$. Plant height at 90 DAS ranged from $82.50 \mathrm{~cm}$ to $98.33 \mathrm{~cm}$ with mean value of $89.60 \mathrm{~cm}$. Significantly maximum plant height at 90 DAS $(98.33 \mathrm{~cm})$ was recorded by $\mathrm{T}_{7}-\mathrm{KNO}_{3}$ (a) 4\% and it was followed by $\mathrm{T}_{2}-$ Mannitol @ 2\% (96.07 cm), $\mathrm{T}_{5}-\mathrm{KCl} @ 4 \%$ (94.30 $\mathrm{cm})$ and $\mathrm{T}_{4}-\mathrm{KCl} @ 2 \%(92.43 \mathrm{~cm})$. Minimum plant height at 90 DAS was recorded by $\mathrm{T}_{0}-$ Control $(82.50 \mathrm{~cm})$. Number of fingers per panicle ranged from 4.80 to 7.47 with mean value of 5.53. Significantly maximum number of fingers per panicle (7.47) was recorded by $\mathrm{T}_{5}-\mathrm{KCl} @ 4 \%$ and it was followed by $\mathrm{T}_{7}-\mathrm{KNO}_{3} @ 4 \%$ (6.47), $\mathrm{T}_{2}$ - Mannitol@2\% (6.13) and $\mathrm{T}_{4}-\mathrm{KCl} @ 2 \%$ (5.87). Minimum number of fingers per panicle was recorded by $\mathrm{T}_{0}-$ Control (4.80). Seed yield per plant ranged from $4.44 \mathrm{gm}$ to $7.90 \mathrm{gm}$ with mean value of $6.27 \mathrm{gm}$. Significantly maximum seed yield per 
plant(7.90 gm) was recorded by $\mathrm{T}_{5}-\mathrm{KCl} @$ $4 \%$ and it was followed by $\mathrm{T}_{7}-\mathrm{KNO}_{3} @ 4 \%$ (7.24 gm), $\mathrm{T}_{2}-$ Mannitol @ 2\% (6.98 gm) and $\mathrm{T}_{4}-\mathrm{KCl} @ 2 \%$ (6.87 gm). Minimum seed yield per plant was recorded by $\mathrm{T}_{0}-$ Control (4.44 gm). Seed yield per plot ranged from $63.60 \mathrm{gm}$ to $142.32 \mathrm{gm}$ with mean value of 95.94 gm. Significantly maximum seed yield per plot(142.32 gm) was recorded by $\mathrm{T}_{5}$ $\mathrm{KCl} @ 4 \%$ and it was followed by $\mathrm{T}_{7}-\mathrm{KNO}_{3}$ @ 4\% (111.00 gm), $\mathrm{T}_{2}$ - Mannitol @ 2\% (105.28 gm) and $\mathrm{T}_{4}-\mathrm{KCl} @ 2 \%$ (102.92 gm). Minimum seed yield per plot was recorded by $\mathrm{T}_{0}-$ Control (63.60 gm). Biological yield ranged from $261.73 \mathrm{gm}$ to $412.89 \mathrm{gm}$ with mean value of $331.61 \mathrm{gm}$.
Significantly maximum biological yield(412.89 gm) was recorded by $\mathrm{T}_{5}-\mathrm{KCl}$ @ 4\% and it was followed by $\mathrm{T}_{9}-\mathrm{CaCl} 2 @$ 4\%(377.51 gm), $\mathrm{T}_{11}$ - Neem leaf extract@ 5\% (363.81 gm)and $\mathrm{T}_{6}-\mathrm{KNO} 3 @ 2 \%$ (360.78 gm). Minimum biological yield was recorded by $\mathrm{T}_{0}-$ Control (261.73 gm). Harvest index ranged from $24.35 \%$ to $34.56 \%$ with mean value of $28.80 \%$. Significantly maximum harvest index $(34.56 \%)$ was recorded by $\mathrm{T}_{5}-\mathrm{KCl} @ 4 \%$ and it was followed by $\mathrm{T}_{7}-\mathrm{KNO}_{3} @ 4 \%$ (33.66\%), $\mathrm{T}_{2}$ - Mannitol @ 2\% (32.79\%) and $\mathrm{T}_{4}-\mathrm{KCl} @ 2 \%(30.65 \%)$. Minimum harvest index was recorded by $\mathrm{T}_{0}-$ Control $(24.35 \%)$.

Table.1 Mean performance of growth and yield characters of finger millet due to effect of presowing seed treatment

\begin{tabular}{|c|c|c|c|c|c|c|c|c|c|c|}
\hline S.No. & Treatments & \begin{tabular}{l}
\multicolumn{1}{c}{ Field } \\
Emergence \\
Percentage
\end{tabular} & $\begin{array}{l}\text { Days to } \\
\mathbf{5 0 \%} \\
\text { Flowering }\end{array}$ & $\begin{array}{c}\text { Plant } \\
\text { height } \\
\text { at } 60 \\
\text { DAS } \\
(\mathrm{cm})\end{array}$ & $\begin{array}{l}\text { Plant } \\
\text { height } \\
\text { at 90 } \\
\text { DAS } \\
(\mathrm{cm})\end{array}$ & $\begin{array}{l}\text { Number } \\
\text { of } \\
\text { Fingers } \\
\text { Per } \\
\text { Panicle }\end{array}$ & $\begin{array}{c}\text { Seed } \\
\text { yield } \\
\text { per } \\
\text { plant }(g)\end{array}$ & $\begin{array}{c}\text { Seed } \\
\text { yield } \\
\text { per plot } \\
\text { (g) }\end{array}$ & $\begin{array}{c}\text { Biological } \\
\text { yield }(g)\end{array}$ & $\begin{array}{c}\text { Harvest } \\
\text { index }\end{array}$ \\
\hline 1 & $\mathbf{T}_{0}$ & 76.33 & 70.00 & 41.07 & 82.50 & 4.80 & 4.44 & 63.60 & 261.73 & 24.35 \\
\hline 2 & $T_{1}$ & 77.67 & 68.67 & 42.33 & 86.63 & 4.93 & 5.57 & 87.00 & 342.37 & 25.42 \\
\hline 3 & $\mathbf{T}_{2}$ & 85.00 & 60.00 & 52.95 & 96.07 & 6.13 & 6.98 & 105.28 & 323.05 & 32.79 \\
\hline 4 & $\mathbf{T}_{3}$ & 82.00 & 66.33 & 44.30 & 85.87 & 5.07 & 6.13 & 79.83 & 300.97 & 26.50 \\
\hline 5 & $\mathbf{T}_{4}$ & 84.00 & 61.00 & 49.03 & 92.43 & 5.87 & 6.87 & 102.92 & 339.58 & 30.65 \\
\hline 6 & $\mathbf{T}_{5}$ & 87.67 & 58.00 & 51.93 & 94.30 & 7.47 & 7.90 & 142.32 & 412.89 & 34.56 \\
\hline 7 & $\mathbf{T}_{6}$ & 83.33 & 63.00 & 46.44 & 87.77 & 5.27 & 6.43 & 100.49 & 360.78 & 28.15 \\
\hline 8 & $\mathbf{T}_{7}$ & 87.00 & 56.33 & 49.48 & 98.33 & 6.47 & 7.24 & 111.00 & 330.22 & 33.66 \\
\hline 9 & $\mathbf{T}_{8}$ & 80.67 & 62.67 & 47.57 & 90.10 & 5.67 & 6.80 & 102.70 & 348.47 & 29.48 \\
\hline 10 & $\mathbf{T}_{9}$ & 86.33 & 64.67 & 45.30 & 88.37 & 5.20 & 6.38 & 104.13 & 377.51 & 27.64 \\
\hline 11 & $T_{10}$ & 77.00 & 69.33 & 42.07 & 84.57 & 4.87 & 4.67 & 70.27 & 283.57 & 24.70 \\
\hline 12 & $T_{11}$ & 80.33 & 65.00 & 44.77 & 88.53 & 5.13 & 6.37 & 99.70 & 363.81 & 27.33 \\
\hline 13 & $T_{12}$ & 78.33 & 67.33 & 43.07 & 89.30 & 5.00 & 5.70 & 78.00 & 265.91 & 29.20 \\
\hline \multicolumn{2}{|c|}{ Grand Mean } & 81.97 & 64.03 & 46.18 & 89.60 & 5.53 & 6.27 & 95.94 & 331.61 & 28.80 \\
\hline \multicolumn{2}{|c|}{ C.D. $(5 \%)$} & 2.84 & 3.05 & 3.10 & 3.86 & 0.45 & 0.35 & 23.26 & 87.42 & 2.27 \\
\hline \multicolumn{2}{|r|}{ SE(m) } & 0.97 & 1.05 & 1.06 & 1.32 & 0.15 & 0.12 & 7.97 & 29.95 & 0.78 \\
\hline \multicolumn{2}{|r|}{ SE(d) } & 1.38 & 1.48 & 1.50 & 1.87 & 0.22 & 0.17 & 11.27 & 42.36 & 1.10 \\
\hline \multicolumn{2}{|r|}{ C.V. } & 2.06 & 2.83 & 3.98 & 2.56 & 4.79 & 3.33 & 14.39 & 15.64 & 4.68 \\
\hline
\end{tabular}

In conclusions the pre-sowing seed treatment (priming) has been used to improve germination, reduce seedling emergence time, improve plant stand establishment and yield. It is the process of controlled hydration of seeds to a level that permits pre-germinative metabolic activity to proceed, but prevents actual emergence of the radicle. Improvement in priming is affected by some factors such as plant species, water potential form priming 
factor, priming duration, temperature, vigour and seed primed storage condition. The beneficial effects of priming have been demonstrated for many field crops. It can enhance rates and percentage of germination and seedling emergence which ensure proper stand establishment under a wide range of environmental conditions.

On the basis of results obtained from the present experiment following conclusions are drawn.

Pre-sowing seed treatment increases the germ inability, significantly in field condition. Presowing treatment with Potassium Chloride (4\%) followed by Potassium Nitrate (4\%), Mannitol (2\%), Potassium Chloride (2\%) and Calcium Chloride(2\%) significantly increased the yield attributes of finger millet. Priming with $\mathrm{KCl}$ and $\mathrm{KNO}_{3}$ showed maximum increase in germ inability of finger millet seeds and found to be lowest in control seeds. Priming of the finger millet seeds for $12 \mathrm{hrs,}$ in which $\mathrm{KCl}(4 \%)$ give best result to enhanced germ inability, growth and yield attributes. These conclusions are based on the results of six months investigation.

\section{References}

Abebe AT, Modi AT. (2009). Hydro-priming in dry bean (Phaseouls vulgris L.). Res. J Seed Sci. 2(2):23-31.

Ahmadvand G, Soleimani F, Saadatian B and Pouya M. (2012). Effect of seed priming on germination and emergence traits of two soybean cultivars under salinity stress. International Research Journal of Applied and Basic Sciences 3: 234-241.

Ajouri A, Asgedom S, Becker M. (2004). Seed priming enhances germination and seedling growth of barley under conditions of $\mathrm{P}$ and $\mathrm{Zn}$ deficiency. $\mathrm{J} \mathrm{Pl}$ Nutri Soil Sci. 16(2):630-636.
Anitha, Mummigatti UV, Jahangirdar S. (2015). Influence of seed priming agents on yield, yield parameters and purple seed stain disease in soybean. $\mathbf{J}$ Agril. Sci. 28(1):20-23.

Anosheh HP, Sadeghi $\mathrm{H}$ and Emam Y. (2011). Chemical priming with urea and KNO3 enhances maize hybrids (Zea mays L.) seed viability under abiotic stress. Journal of Crop Science and Biotechnology 14: 289-295.

Assefa MK and Hunje R. (2011). Standardization of seed priming duration in soybean [Glycine max (L.) Merill]. Seed Research 39: 1-4.

Bajehbaj AA. (2010). The effects of $\mathrm{NaCl}$ priming on salt tolerance in sunflower germination and seedling grown under salinity conditions. African. J. Biotech.9 1764-1770.

Binang, W.B., Shiyam, J.Q. and Ntia, J.D. (2012). Effect of seed priming method on agronomic performances and cost effectiveness of rainfed, dry-seeded NERICA rice. Research Journal of Seed Science. 5:136-143.

Caseiro, R., Bennett, M.A. and Marcos, Filho. J. (2004). Comparison of three priming techniques for onion seed lots differing in initial seed quality. Seed Sci Tech. 32: $365-375$.

Chavan NG, Bhujbal GB and Manjare MR. (2014). Effect of seed priming on field performance and seed yield of soybean [Glycine max (L.) Merill] varieties. Bioscan 9: 111-114.

Demir, I., and Oztokar, C., (2003). Effect of salt priming on germination and seedling growth at low temperature in watermelon seed during development.Seed science and technology,31:765-770.

Devi, PB., Vijayabharathi, R., Sathyabama, S., Malleshi, NG., and Priyadarisini, VB. (2011). Health benefits of finger millet (Eleusine coracana L.) 
polyphenols and dietary fiber: A Review. J Food Sci Technol DOI: 10.1007/s13197-011-0584-9.

Dursun, A. and Ekinci. M. (2010). Effects on different priming treatments and priming durations on germination percentage of parsley (Petroselinum crispum L.) seeds. Agricultural Sciences. 1(1): 17-23.

Elkoca, E., Haliloglu, K., Eşitken, A. and Ercişli, S. (2007). Hydro- and osmopriming improve chickpea germination. Acta Agriculture Scandinavica Section B-Soil and Plant Science. 57: 193-200.

Elouaer, M. A and Hannachi, C., (2012). Seed priming to improve germination and seedling growth of safflower (Carthamus tinctorius) under salt stress. EurAsian Journal of BioSciences, 6: 7684.

Ganesh KS, Sundaramoorthy P, Baskaran L, Rajesh M, Rajasekaran S. (2013). Effect of pre-sowing hardening treatments using various plant growth hormones on two varieties of green gram germination and seedling establishment. Int. J Modern Biol. Med. 3(2):78-87.

Ghassemi-Golezani, K., Aliloo, A.A., Valizadeh, M.and Moghaddam, M. (2008). Effects of Different Priming Techniques on Seed Invigoration and Seedling Establishment of lentil (Lens culinaris Medik.). Journal of Food, Agriculture and Environment. 6(2): 222-226.

Karivaratharaju TV, Ramakrishnan V. (1985). Seed hardening studies in two varieties of ragi (Eleusine coracanna). Indian $\mathbf{J}$ Plant Physiol. 28(3):243-248.

MaasoumehAsadi, Aghbolaghi and Mohannadsedghi. (2014). The effect of osmo and hormone priming on germination and seed reserve utilization of millet seeds under drought stress. Journal of stress physiology \& biochemistry.10 (1).214-221.

Maitraa S, Jana PK, Roy RK. (1999). Effect of varieties and presowing seed treatment on yield, quality and nutrient uptake by finger millet under lateritic belt of West Bengal. Ann. Agric. Res. 20:360-364.

McDonald MB. (2000). Seed Priming. In: Seed Technology and its Biological Basis, Black, M. and Bewley, J. D. (Eds.). Shefield Academic Press, Shefield, UK, 287-325.

Mehta, D. IC, Kanwar, H. S., Thakur, A. K. and Thakur, K. S., (2010) Influence of organic seed priming on germination and seedling quality in bell pepper \{Capsicum annuum L.). Journal of Hill Agriculture. (1):85-87.

Moghadam AK, Mohammadi K. (2013). Different priming treatments affected germination traits of safflower. App Sci Rep 2, 22-25.

Mohan Kumar, G. and V. Manonmani, (2011). Standardisation of seed priming and its influence on biochemical changes in germination of sunflower seeds. Proceeding of National Seed Congress held at January 25-26, Pune, India, pp:209-212.

Oliveira, A.B.D and Gomes-Filho, E. (2016). How are germination performance and seedling establishment under abiotic stress improved by seed priming? A review. Australian Journal of Crop Science. 10 (7): 1047-1051.

Padmavathi S, GunasekarJ, Kamaraj A, (2017). Effect of presowing seed treatment using botanical extract on growth and yield characters in blackgram (Vigno mungo L.). Plant Archives Vol. 17 No. 2, 2017 pp. 10131016.

Sridevi, R. and Manonmani, V., (2016). Seed priming effect on physiological traits of kodo millet and barnyard millet. Int. $J$. Agric. Sci. Res., 6(2): 759-772. 


\section{How to cite this article:}

Nuthalapati Karthik, Arun Kumar Chaurasia, Rajaka Karthik Kumar and Karunakar Reddy Guduri. 2021. Evaluation of Different Pre-sowing Seed Treatment for Improving Growth, Yield and Yield Attributes of Finger Millet (Eleusine coracana (L.) Gaertn). Int.J.Curr.Microbiol.App.Sci. 10(02): 243-249. doi: https://doi.org/10.20546/ijcmas.2021.1002.030 